\title{
Archimedean Antenna Design with Ultra-Ease "Green" Modules
}

\author{
Karthik.B, MeenaKumariG, Jasmin.M.
}

\begin{abstract}
An investigation is done for a Archimedean winding radio wire in acknowledgment of a developing idea to coordinate Radio-frequency identification alongside a few outcomes by utilizing a solitary radio wire. The reception apparatus is created utilizing best in class inkjet printing innovation on different monetarily accessible to give the minimal effort, litheRadio-frequency modules for the people to come of "green" gadgets. The effects on electromagnetic qualities of the planar Archimedean winding radio wire, because of the utilization of paper are researched other than different readings. The projected reception apparatus is assessed in addition to upgraded for equipped series from $0.8\{3.0 \mathrm{GHz}$. It displays excellent scope all through various RFID ISM groups so accomplish for different remote applications.
\end{abstract}

Keywords :Antenna,Modu;les,Ultra-Ease.

\section{INTRODUCTION}

It is viewed as a developing driving innovation in future broadcast communications, programmed identification and information catch (AIDC) enterprises. The RFID showcase has developed in a two-dimensional pattern one side constitutes standalone RFID frameworks which are generally found at present. Then again, more contemporary approach is clearing its direction, where RFID should be coordinated with wide equipped exhibit of unmistakable applications for the stage dissimilar capacities as well as route, broadcasting, and individual correspondence, to say a couple. Utilizing dissimilar radio wires to incorporate all correspondence groups is a direct approach, however in the meantime, it prompts expanding price, mass, more surface zone for establishment, or more all electromagnetic similarity issues .[1-5]

In this manner, there is the need for wide-transfer speed reception apparatuses. The embrace of a solitary, little measured wideband reception apparatus is surely more appealing on the grounds that RFID is supplanting other recognition strategies by shrieking about more capable arrangements. The elements of winding receiving wire brought it to the spotlight in late writing, especially for scaling down.

The essential motivation for scaling down is to back off the wave going inside the reception apparatus structure.

Revised Manuscript Received on August 22, 2019.

Karthik.B Assistant Professor, Department of Electronics And Communication Engineering,, Bharath Institute of Higher Education and Research, Chennai, India. karthikguru33@gmail.com

MeenaKumariG, Assistant Professor, Department of Electronics And Communication Engineering,, Bharath Institute of Higher Education and Research, Chennai, India. meensg85@gmail.com

Jasmin.M, Assistant Professor, Department of Electronics And Communication Engineering, Bharath Institute of Higher Education and Research, Chennai, India. rifriz@gmail.com
Various methodologies have been sought after to accomplish it, stacking, artificial materials, winding arm forming, disseminated responsive stacking and arm situating vertically .On the other hand, when utilizing the prominent dielectric stacking approach, the info impedance is additionally brought down. Then again. Most by far of circuits created on PCB utilize FR-4; along these lines this volumetric outline or scaling down is profound.[6-9]

This article gives parametric investigation of a flexible, wideband Archimedean reception apparatus, which is created by using an extraordinarily capable and minimal effort inkjet printing strategy for printing "green" conformal electronic circuits. Natural materials do have a tendency of extra loss at higher frequencies, because of their similarity to water. Be that as it may, by utilizing the adjust paper sort., sufficient radio recurrence execution is accomplished on paper-based RF circuit outlines. The plan and reproductions are performed utilizing ANSYS HFSSTM, while; the estimations are performed in an anechoic chamber committed to reception apparatus portrayal. The proposed receiving wire effectively works all through the operational scope of intrigue, along these lines extending the degree of all the while incorporating a few remote modules while creating eco-accommodating modern arrangements.[10-15]

\section{II "GREEN" ANTENNAS EVOLUTION:}

The imaginative idea of "green" broadband receiving wires sustained new arrangement of values that compose the planned outline stages specified. As opposed to customary plan flow, each phase of "green" development is stacked with a novel grid of components which should be assessed for reconciliation with electronic gadgets.

\section{III.SYNTHESIS OF THE ANTENNA TOPOLOGY}

With a specific end goal to accomplish even broadband multimode include multimode highlight in close fields planar Archimedean winding receiving wire structure is figured it out. Three plans of Archimedean winding radio wire are surveyed. The inside and out research demonstrates that the Archimedean winding is not a recurrence autonomous receiving wire structure since the dispersing between the arms is specified by a consistent, not an edge . Be that as it may, this is an antagonistic point on the grounds that essentially recurrence autonomous execution is accomplished more than 10 : 1 data transmissions. The accompanying numerical figuring are misused to build the proposed reception apparatus structure. The centerline of the planned Archimedean reception apparatus is given by:[16-18] 
Where also, $\mathrm{C}$ is the point of pivot which relies on upon $\mathrm{K}$. to be measured to a recurrence that is $\mathrm{K}$ times lesser.

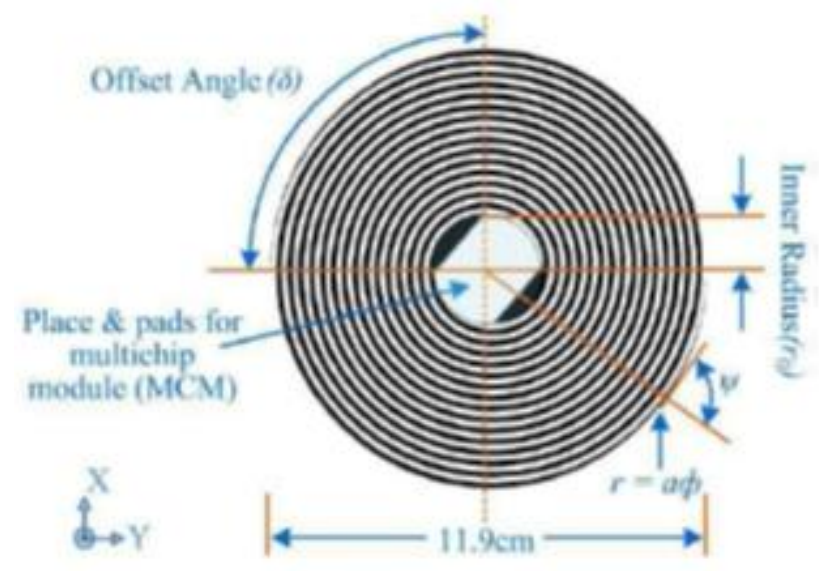

Fig 1. Magnitude \& "green" theme of planned antennas

The two-arm winding radio wire planned for recurrence band $0.8 \mathrm{GH}$ ]. Given that the widths and spacing are defined by constants instead of by edges, Archimedean winding radio wire don't adjust to either the recurrence autonomous or log-intermittent standards. In this way, this receiving wire offers self-rule to those ASIC producers which have recurrence subordinate modules. In hone, it is watched that recurrence autonomous attributes are acquired if is sufficiently substantial in the dynamic area, wherein the periphery of the ring is around one length. Oh, modest data has been distributed $[12,29]$ on the corruption of pick up and designs. Few distributed results demonstrate the freely twisted log-winding executes and additionally the firmly wound Archimedean spirals; be that as it may, this investigation is out of extent of this article.[19]

\section{IV.DEVELOPING PARAMETRIC ANALYSIS}

\section{A.. Antenna Routine}

It is settled that the width of the written plan has to be bigger or nearer to the estimation of skin profundity so as to accomplish ideal execution. For a typical conductor, the skin profundity

can be registered as

where $\mathrm{f}$ - recurrence. The skin profundity for hints of the planned receiving wire with equipped recurrence at $800 \mathrm{MHz}$ is assessed utilizing Equation. It is declared after watchful emphases that no less than three layers printing by Cabot ink and four layers printing by Xerox ink, are sufficient to accomplish better execution under the breaking points forced by different plan components.

Then again if the quantity of turns are decreased, the pick up of the receiving wire abatements to an esteem which disregards the outline necessities in light of the fact that these labels are projected for huge things plane attaching and data grouping. So it is required for the radio wire to show better pick up to accomplish higher read go also giving intelligibility in the close old district. Additionally, due to the utilization of costly conductive ink, the span of the receiving wire must be inside temperate breaking points for its conceivable acknowledgment on modern scale. Along these lines, the ideal plan example is accomplished while considering as far as possible alongside other execution components reach from $0.8\{3.0 \mathrm{GHz}$ is acknowledged with 7.5-turns.

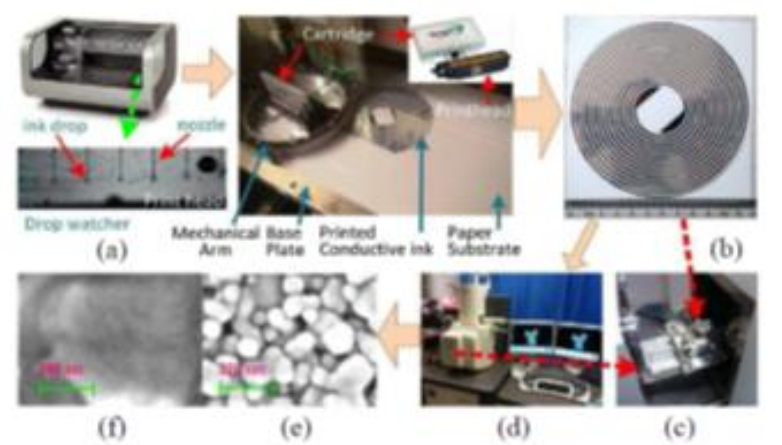

Fig2 : Inkjet Printer

\section{B.Inkjet Printing:}

Inkjet printing depends on the drop-on-request (DOD) system by which the fancied outline is exchanged straight forwardly to the substrate. This innovation requires no veils contrasted and the routine drawing method, which has been regularly utilized as a part of generation, in this way, making no waste, following in a temperate and

eco-accommodating assembling decision. While, the proposed structure, uses more ink than, however this cost is completely justice for excellent level of functionalities offered by the structure.

The inkjet printer utilized as a part of this examination is Dalmatic DMP2800 which is a tabletop printer as appeared. It utilizes one client liable inkjet print cartridge which contains 16 spouts in a solitary push with the separating two back to back spouts is $254 \mathrm{~m}$, and the substrate is detained by vacuum plate. It demonstrates the drop watcher perspective of ink drops of $10 \mathrm{pl}$ in volume are catapulting out of DMC-11610 print cartridge that can be filled upto $1.5 \mathrm{ml}$. The receiving wire arrangement on Felix Scholar paper by utilizing Cabot conductive ink that contains silver strong stacking of $19 \mathrm{wt} \%$. Moreover, printing readings are enhanced for all paper substrate sorts utilizing. Ink use for taking Xerox has silver stacking of $40 \mathrm{wt} \%$. The advanced flying voltage acknowledged for both inks is $16 \mathrm{~V}$ with the speed of $5 \mathrm{~m} / \mathrm{s}$.

The spout heat is maintained at room temperature, and the substrate vacuum plate, whose temperature is controllable, is maintained at $40 \pm \mathrm{C}$ when printing with both inks. So as to maintain the reliability of performing top to bottom examination, every blend is printed with $20 \mu$ drop that divids and print determination of $1270 \mathrm{dpi}$. The printer is furnished with Fiducially Camera, which gave the simplicity of substrate arrangement utilizing reference stamps, and situating a print starting point or reference indicate coordinate substrate situation. Besides, it is utilized for assessment of elements and areas alongside assessment and picture catch of printed example or drops.[20] 


\section{V.FIELD \& CIRCUIT CONCEPTS PARAMETRIC ANALYSIS}

The proposed radio wire that gives better return misfortune is not exactly $15 \mathrm{~dB}$ all through the recurrence group of intrigue (and in expert articulation that is, the central prerequisite of reception apparatuses for ideal execution. Besides, the steady reaction of paper substrate at higher frequencies, (despite the fact that with a specific measure of varieties however inside satisfactory qualities) make it a reasonable competitor for broadband receiving wires. Generally, a great understanding in the middle of the registered, Xerox ink printed, and the Cabot ink printed radio wires is seen in spite of the higher loss of the silver-based inks. 15]

The radiation which is an example is measured inside a chamber setup that produces supreme free space. The winding radio wire under test is set on a position gathering, which is set to turn the reception apparatus in little to acquire a $360 \pm$ radiation design. A persistent wave $(\mathrm{CW})$ motion from the flag generator energizes the AUT. The beneficiary reception apparatus is associated with the range analyzer (Agilent HP $8562 \mathrm{E}$ ) and a PC running the test computerization programming controls the estimation setup. The deliberate standardized radiation examples (of radio wire imprinted on Kodak photo paper utilizing Cabot ink) at trademark frequencies of $3.0 \mathrm{GHz}$ are plotted.

It is watched that the greater part of the radiation designs that has typical shape and show extraordinary similitude amongst calculations and estimations, which can likewise be verified for different frequencies inside the radio wire transfer speed and are in cognizance with beforehand distributed comes about Furthermore, the deliberate radiation designs show a slight onset because of the nourish line interfacing. It can be delineated from the radiation design does not decay in the entire transfer speed from $0.8\{3.0 \mathrm{GHz} .[14]$

\section{CONCLUSION}

In this document, wideband winding reception apparatuses manufactured on paper substrate for at the same time actualizing a wide scope notwithstanding, RFID tag has been proposed. It is noticed that changing the hole contiguous tracks to make the winding arms prompts a bigger inside similar gap estimate. All the already distributed applicable work as opposed, is centered around complex methods, to make such reception apparatuses utilizing non flexible or sullied substrates, which not one or the other can be executed with move to-move printing nor reasonable for eco- cordial applications. In spite of the fact that the displayed research is specified to inkjet printed Archimedean winding reception apparatuses, similar approach can be connected to different radio wires made of printed bands, to shape modules for "green" gadgets.

\section{REFERENCES}

1. Kongkham, D. \& Sundararajan, M. 2019, "Distributed wideband sensing method for faded dynamic spectrum access", International Journal of Innovative Technology and Exploring Engineering, vol. 8, no. 10, pp. 4309-4312.

2. Balaji, S., John Paul Praveen, A. \& Mohanraj, R. 2019, "Recognizable proof and analysis of palm print in biometric authentication system using bayes techniques", International Journal of Innovative Technology and Exploring Engineering, vol. 8, no. 9 Special Issue 3, pp. 1126-1129.
3. Kavitha, G., Priya, N., Velvizhi, R. \& Allin Geo, A.V. 2019, "Parallel computation in correspondence and signal processing", International Journal of Innovative Technology and Exploring Engineering, vol. 8, no. 9 Special Issue 3, pp. 1136-1139.

4. Hema, R., Sundararajan, M. \& Balaji, S. 2019, "Smartphone control robot with automatic firing gun", International Journal of Innovative Technology and Exploring Engineering, vol. 8, no. 9 Special Issue 3, pp 625-627.

5. Kaliyamurthie, K.P., Sundar Raj, B., Velvizhi, R. \& Shanmugapriya, K. 2019, "Dual band paper substrate CPW antenna for wireless applications", International Journal of Innovative Technology and Exploring Engineering, vol. 8, no. 9 Special Issue 3, pp. 605-608.

6. Geo, A.V.A., Arunachalam, A.R., Michael, G. \& Elankavi, R. 2019, "Evaluating architecture using compact modalities", International Journal of Innovative Technology and Exploring Engineering, vol. 8, no. 9 Special Issue 3, pp. 836-838.

7. Theivasigamani, S., Jeyapriya, D. \& Anita Davamani, K. 2019, "Anamoly analyzing and exploring for wireless sensor networks", International Journal of Innovative Technology and Exploring Engineering, vol. 8, no. 9 Special Issue 3, pp. 1116-1118.

8. Jeyapriya, D., Theivasigamani, S., Velvizhi, R. \& Nandhini, P. 2019 , "Program detection in wireless feeler networks", International Journal of Innovative Technology and Exploring Engineering, vol. 8, no. 9 Special Issue 3, pp. 1194-1195.

9. Gowri Sankaran, B., Karthik, B. \& Vijayaragavan, S.P. 2019, "Image compression utilizing wavelet transform", International Journal of Innovative Technology and Exploring Engineering, vol. 8, no. 10, pp. 4305-4308.

10. Gowri Sankaran, B., Karthik, B. \& Vijayaragavan, S.P. 2019, "Weight ward change region plummeting change for square based image huffman coding", International Journal of Innovative Technology and Exploring Engineering, vol. 8, no. 10, pp. 4313-4316.

11. Hema, R., Sundararajan, M. \& Balaji, S. 2019, "Smartphone control robot with automatic firing gun", International Journal of Innovative Technology and Exploring Engineering, vol. 8, no. 9 Special Issue 3, pp. 625-627.

12. Rangaswamy, K. \& Rajabhushanam, C. 2019, "Congestion control in wireless network using TCP friendly rate control (TFRC)", International Journal of Recent Technology and Engineering, vol. 8, no. 2 Special issue 3, pp. 1598-1602.

13. Tamil Selvan, S. \& Sundararajan, M. 2019, "Performance Parameters of 3 Value 8t Cntfet Based Sram Cell Design Using H-Spice", International Journal of Recent Technology and Engineering, vol. 8, no. 2 Special issue 5, pp. 22-27.

14. Vinoth, V.V. \& Kanniga, E. 2019, "Steganographical techniques in hiding text images - system", International Journal of Recent Technology and Engineering, vol. 8, no. 2, pp. 6535-6537.

15. Saravana, S., Balaji, S., Arulselvi, S. \& John Paul Praveen, A. 2019 "Reliable power quality monitoring and protection system", International Journal of Innovative Technology and Exploring Engineering, vol. 8, no. 9 Special Issue 3, pp. 644-645.

16. Sundaramoorthy, A. \& John Wiselin, M.C. 2019, "Single patch antenna with multiple feed", International Journal of Innovative Technology and Exploring Engineering, vol. 8, no. 9, pp. 1743-1747.

17. Velavan, R., Bharanidharan, S. \& Sheeba, B. 2019, "EMF pollution Causes, effects and protection", International Journal of Innovative Technology and Exploring Engineering, vol. 8, no. 9 Special Issue 3, pp. 1166-1168.

18. Veer, R.A., Arulselvi, S. \& Karthik, B. 2019, "Construction of ensemble square classification approaches in MIMO OFDM", International Journal of Engineering and Advanced Technology, vol. 8, no. 5, pp. 2039-2041.

19. Agitha, W. \& Kaliyamurthie, K.P. 2019, "Improved energy efficient in WBAN using MAC with cloud computing", International Journal of Innovative Technology and Exploring Engineering, vol. 8, no. 8, pp. 2405-2408.

20. Kastro, G.G. \& Wiselin, M.C.J. 2019, "Design and analysis of stub loaded resonator", International Journal of Recent Technology and Engineering, vol. 8, no. 1 Special Issue4, pp. 272-283. 


\section{AUTHORS PROFILE}

Karthik.B Assistant Professor, Department of Electronics And Communication Engineering,, Bharath Institute of Higher Education and Research, Chennai, India..

MeenaKumariG, Assistant Professor, Department of Electronics And Communication Engineering,, Bharath Institute of Higher Education and Research, Chennai, India.

Jasmin.M, Assistant Professor, Department of Electronics And Communication Engineering,, Bharath Institute of Higher Education and Research, Chennai, India.. 